8. Енциклопедичний словник символів культури України / за заг. ред. В.П. Коцура, О.І. Потапенка, В.В. Куйбіди. 5-е вид. КорсуньШевченківський: ФОП Гавришенко В.М., 2015. 912 с.

9. Караванський С. Практичний словник синонімів української мови. Київ : «Українська книга», 2000. 480 с.

10. Коцюба З.Г. Рефлексія побутової свідомості в різномовному провербіальному просторі (від універсального до національного) : монографія. Львів : ДП «Видавничий дім «Укрпол», 2010. 472 с.

11. Купер Дж. Энциклопедия символов. Серия «Символы». Кн. IV. Москва: Ассоциация духовного единения «Золотой Век», 1995. 411 с.

12. Мацюк 3. Що сільце, то нове слівце: словник фразеологізмів Західного Полісся. Луцьк : Вежа-Друк, 2013. 476 с.

13. Прислів'я та приказки: Людина. Родинне життя. Риси характеру. упоряд. М. М. Пазяк. Київ: Наукова думка, 1990. 528 с.

14. Словник української мови. Академічний тлумачний словник (1970-1980). URL: http://sum.in.ua

15. Ужченко В.Д. Народження і життя фразеологізму. Київ: Рад.шк., 1988. $279 \mathrm{c}$.

16. Українські приказки, прислів'я і таке інше. Уклав М. Номис / Упоряд., приміт. та вступна ст. М. М. Пазяка. Київ: Либідь, 1993. 768 с.

DOI https://doi.org/10.30525/978-9934-26-073-5-1-74

\title{
VERBALIZATION OF COSMOLOGY IN THE CONCEPTUAL SYSTEM OF UKRAINIAN AND FRENCH-SPEAKING BELGIAN SYMBOLIST POETRY
}

\author{
Chystiak D. 0. \\ Doctor of Philological Sciences, \\ Associate Professor at the Department of Romanic Philology \\ Institute of Philology \\ Taras Shevchenko National University of Kyiv \\ Kyiv, Ukraine
}

This research is devoted to the cosmological conceptual system, verbalized in Ukrainian and Belgian Symbolist poetry already analyzed in our previous works $[1 ; 2 ; 3]$. The poetic vocabulary of both national traditions reflects basic ideas and images of mythical cosmogony, structure of space and time, anthropomorphic, zoomorphic and other personifications of the universe and 274 
its parts, especially higher (astral, divine), medial (terrestrial, human) and lower (underground, water, demonic) levels of cosmos. This structure reflects an archaic mythical three-level division of space that is a universal (archetypical) cosmological concept.

The symbol, differently verbalized in the texts of Symbolist poetry, is interpreted as a mythological sign, reflecting the pre-rational worldview where associations of images strongly prevailed over the logical connections between ideas. The poetic thought revives this way of thinking creating new texts of new mythology. Words and word combinations as well as verbalizing symbols represent key concepts of magic and mythical image of the universe.

The symbolic language of poetry transformed the language of myth according to the individual stylistic manner of each author, national poetic tradition as well as the individual interpretation of universal and ethno-national conceptual archetypes etc. Verbalized concepts consist of individual, national and universal components.

The main result of this research is the identification of basic mythic protoconceptual systems that were substrata for the poetic cosmology in every national tradition. Ancient Ukrainian pre-Christian paganism was the basis for the Ukrainian Symbolist cosmological concepts whereas Ancient Greek and Roman mythology was a substratum for the Belgian symbolist cosmological concepts. Therefore, the conceptual system of cosmology was inherited from the folklore in Ukrainian symbolist poetry but was taken from literary sources in Belgian symbolist poetry. There were concepts, representing national archetypes for the Ukrainian authors that were not relevant for the Belgian Symbolists. The research has shown that the poetic myth, reflected in the worldview of Symbolist poetry (especially in its basic, cosmological conceptual system), is a literary reconstitution of pre-Christian mythology, for the Ukrainian poets, and a literary interpretation of the Greco-Roman mythical world, for Belgian poets.

The texts of Ukrainian Modernism (and especially those of Symbolists) are generating different ways of verbalization of national ideals. They are oriented in the pagan Past (interpreted in a specific way by each author) and in the Future where the Nation should be created to perform the national ideals and the European values. The key concepts of national Ukrainian Symbolist poetry are generating not only elements of pagan worldview but also Christian imagery (especially the cosmologic and apocalyptic concepts of Creation and End of Times), several concepts of Ancient Greek mythology, as well as some symbolic concepts of the historical past and some contemporary (for the time of creation of Symbolist texts) patterns of revolutionary texts. We find in these 
tendencies of Ukrainian Symbolist texts the dialectics of universal and ideo-ethnic.

The pre-Christian structures of conceptual worldview were not really relevant for the Belgian Symbolist literary creation as they were for Ukrainian Symbolists in the actualization of pre-historical pagan mythology. For the Belgian Symbolists this role was performed by the new artistic interpretation of the key concepts of Ancient Greek and Roman worldview, an ideological basis for the contemporary European civilization. We can see that such a tendency correlates with the Ukrainian Neo-Classicist texts whereas Ukrainian Symbolist texts are much more oriented towards the Romanticism with its resurrection of Folklore and National ideals.

In the Belgian Symbolist texts we find the cosmologically marked scheme of the passage from the negatively marked conceptual sphere DOWN WORLD to the positively marked or neutrally connoted conceptual sphere UPPER WORLD that is the realization of the Animist conceptualization SKY $=$ GOOD LUCK. For example, in the poetry of Georges Rodenbach and Emile Verhaeren we find the passage of concept SOUL from positively and negatively marked conceptual spheres WATER and LIGHT to the positively marked conceptual sphere UPPER WORLD. In the poetry of Maurice Maeterlinck we observe the negatively marked DOWN WORLD and the projection of SOUL to the positively and negatively marked UPPER WORLD.

The neutralization of CHAOS marked by the concepts COLD and DARKNESS is shown in the poetry by Max Elskamp, whereas in the texts of Gregoire Le Roy the synthesis of positively marked PAST and negatively marked PRESENT is generated in the neutrally marked Cosmos of DEATH and LOVE in the FUTURE. In the poetry of Charles Van Lerberghe we observe the passage from the positively marked COSMOS of the UPPER WORLD to the negatively marked CHAOS where are interacting the UPPER and DOWN WORLDS with the possible synthesis in the COSMOS of ETERNITY.

We can conclude that basic conceptual oppositions (LIGHT-DARKNESS, TOP-BOTTOM, PAST-FUTURE, LIFE-DEATH) and conceptual formulas of the text (the sequence of first concepts, verbalized in the text) are used for the interpretation of the poetic texts of Ukrainian and Belgian Symbolists. These approaches has demonstrated peculiarities not only of the archaic mythical worldview (where cosmological basic elements were nuclear) but also those of the more developed Christianized worldview (where concepts of moral life, like GOOD-DEMON, GOOD-EVIL, are verbalized a lot). 


\title{
References:
}

1. Chystiak D.O., Mosenkis I.L. L'Intérieur et l'extérieur dans le premier théâtre de Maurice Maeterlinck. Studii si cercetari filologice. Seria Limbi Romanice. Pitesti, 2020. No. 27. P. 58-73.

2. Chystiak, D. Mythological poetic cosmology in the language of Ukrainian and Belgian symbolist poetry. Kyiv, Summit-Knyga, 2018. 684 p.

3. Chystiak D. Mythological poetic worldview in Belgian Symbolism. Kyiv, Raduga, 2016. 272 p.

DOI https://doi.org/10.30525/978-9934-26-073-5-1-75

\section{ЛІНГВОСТИЛІСТИЧНІ ТА ЕКОЛІНГВІСТИЧНІ ОСОБЛИВОСТІ ТВОРЧОСТІ ФЕНІМОРА КУПЕРА}

\author{
Чрділелі Т. В. \\ кандидат філологічних наук, доцент, \\ дочент кафедри перекладу \\ Кременчуиького національного університету \\ імені Михайла Остроградського \\ Якимець М. С. \\ аспірантка \\ Кременчуиького національного університету \\ імені Михайла Остроградського \\ м. Кременчук, Полтавська область, Україна
}

Показовою віхою розвитку сучасної лінгвістики $є$ не тільки ii антропоцентризм, але й поєднання наукових парадигм, тобто застосування теоретичних та методологічних засад суміжних дисциплін. Одним із таких нових напрямків є еколінгвістика, яка вводить ідеї гармонічного розвитку природи до мовознавчих студій. Як стверджує О. Іванова, ця наука поєднує екологію і лінгвістику, вона вивчає взаємодію між мовою, людиною та оточуючим середовищем, а мова при цьому розглядається як невід'ємний компонент ланцюга взаємовідносин між людиною, суспільством та природою [1, с. 2]. Виходячи із такого розуміння завдань еколінгвістики, можна вважати, що одним iз перспективних джерел досліджень у парадигмі цієї науки $є$ аналіз художніх текстів, які торкаються проблем взаємодії людини з оточуючим середовищем, навколишнім світом. Саме це визначило наш вибір на 